\title{
Correction to: Serum magnesium, mortality and disease progression in chronic kidney disease
}

Rami Azem ${ }^{1}$, Remy Daou², Elias Bassil ${ }^{3}$, Eva Maria Anvari ${ }^{1,4}$, Jonathan J. Taliercio ${ }^{1,4}$, Susana Arrigain ${ }^{5}$, Jesse D. Schold ${ }^{5}$, Tushar Vachharajani ${ }^{1,4}$, Joseph Nally ${ }^{1,4}$ and Georges N. Nakhoul ${ }^{1,4^{*}}$

\section{Correction to: BMC Nephrology (2020) 21:49. https://doi.org/10.1186/s12882-020-1713-3}

Following publication of the original article [1], we have been notified that the name of one author was spelled incorrectly as Georges N. Na khoul, when the correct spelling is Georges N. Nakhoul.

\begin{abstract}
Author details
'Department of Nephrology and Hypertension, Glickman Urological and Kidney Institute, Cleveland Clinic, 9500 Euclid Avenue - Q7, Cleveland, OH 44195, USA. ${ }^{2}$ Department of Family Medicine, Saint Joseph University, Beirut, Lebanon. ${ }^{3}$ Department of Internal Medicine, Cleveland Clinic, Cleveland, $\mathrm{OH}$, USA. ${ }^{4}$ Cleveland Clinic Lerner College of Medicine of Case Western Reserve University, Cleveland, OH, USA. ${ }^{5}$ Department of Quantitative Health Sciences, Cleveland Clinic, Cleveland, OH, USA.
\end{abstract}

Published online: 17 April 2020

\section{Reference}

1. Azem et al. BMC Nephrology (2020) 21:49 https://doi.org/10.1186/s12882020-1713-3.

\footnotetext{
The original article can be found online at https://doi.org/10.1186/s12882020-1713-3.

* Correspondence: nakhoug@ccf.org

'Department of Nephrology and Hypertension, Glickman Urological and Kidney Institute, Cleveland Clinic, 9500 Euclid Avenue - Q7, Cleveland, OH 44195, USA

${ }^{4}$ Cleveland Clinic Lerner College of Medicine of Case Western Reserve University, Cleveland, OH, USA

Full list of author information is available at the end of the article
}

(C) The Author(s). 2020 Open Access This article is licensed under a Creative Commons Attribution 4.0 International License, which permits use, sharing, adaptation, distribution and reproduction in any medium or format, as long as you give appropriate credit to the original author(s) and the source, provide a link to the Creative Commons licence, and indicate if changes were made. The images or other third party material in this article are included in the article's Creative Commons licence, unless indicated otherwise in a credit line to the material. If material is not included in the article's Creative Commons licence and your intended use is not permitted by statutory regulation or exceeds the permitted use, you will need to obtain permission directly from the copyright holder. To view a copy of this licence, visit http://creativecommons.org/licenses/by/4.0/ The Creative Commons Public Domain Dedication waiver (http://creativecommons.org/publicdomain/zero/1.0/) applies to the data made available in this article, unless otherwise stated in a credit line to the data. 